\title{
THE IMPACTS ON LEADERSHIP, OFFICIAL'S COMPETENCE, ORGANIZATIONAL CULTURE AND PARTICIPATION OF PEOPLE TOWARD THE QUALITY OF INTEGRATED LICENSING SERVICES ON TRADING BUSINESS LICENSE (SIUP) IN BEKASI CITY
}

\author{
Ismaniah \\ Ph.D candidate \\ Satyagama University, Jakarta- Indonesia \\ Josy Adiwisastra \\ Professor of Public Policy Field of Government Science \\ Pajajaran University, Bandung-Indonesia \\ Musa Hubeis \\ Professor of Public Policy field of Government Science \\ Agricultural Institute, Bogor -Indonesia \\ Hariatia Ambiar \\ Senior Lecturer \\ Satyagama University \\ DOI: $10.31364 / \mathrm{SCIRJ} / \mathrm{v} 8 . \mathrm{i} 2.2020 . \mathrm{P} 0220742$ \\ http://dx.doi.org/10.31364/SCIRJ/v8.i2.2020.P0220742
}

\begin{abstract}
This study has a purpose to know the impacts on leadership, official's competence, organizational culture and participation of people toward the quality of integrated licensing services on trading business license (SIUP) in Bekasi City, West Java, Indonesia. Noneffectiveness of the implementation of integrated licensing services on SIUP in Bekasi City is a significant meaning of this study. The method of this study uses a quantitative approach as an instrument to collect data by making survey through questionnaire and field observation. In addition, secondary data is obtained from district government that is published through BPS and DPMPTSP Bekasi. Then, this data is analized statistically by using multiple regression analysis. The result of study indicates that leadership, official's competence, organizational culture and participation of the people, either partially or collectively, have significant impacts on the quality of integrated licensing services on trading business license (SIUP) in Bekasi City. Thus, in order to make the implementation of integrated services more effective, it needs effort to improve creative, active and innovative leadership and to have high integrity through education and training; improve the official's competence through the improvement of analytical thinking capability; strengthen organizational culture through the improvement of innovation and detailed things as well as increase the involvement of people in integrated licensing services through socializations to the community and the
\end{abstract}

use of communication media through e-government of Bekasi City.

Key Words: leadership, official's competence, organizational culture, participation of people, quality of services, trading business license (SIUP).

\section{RESEARCH BACKGROUND}

In these last 10 years, Bekasi City has been rapidly developed in terms of population and economic growth where it can be seen from the shopping centers and offices that are more crowded and it indicates that an Original Local Government Revenue (PAD) of Bekasi City also continuously increases. Many domestic investors make a trading investment because Bekasi City has quite high competitiveness. According to Adam Smith, the emergence of improvement in one sector shall increase the attractiveness of capital formation, encourage technology advances, improve specialization and expand the market.

As a city of destination for investment, fast, easy and transparent processes of licensing services are really needed, among others a licensing service of SIUP, namely a Trading Business License. But then, such licensing service may not meet the expectation of the people where it can be seen from many complaints of the people, either directly complained to the head of a service unit or to the reader's letter in various 
mass-media. On the other side, the people as the main element of being served may not give effective control to become a driving force in an effort to improve the quality of public services.

The quality of public services is a reference to measure or observe a region whether it is successful or less-successful in applying a decentralization system or as an autonomous region. For this reason, it is necessary to have evaluation criterions that indicate whether such public services provided by government officials can be said good or bad, being qualified or not. In this case, Zeithaml et.al. (1990) states that SERVQUAL is an empirical method that can be used by a service organization to improve the quality of service.

a. According to Abussamad (2014:7), the success of organizations of district government in performing its mission, especially in term of providing a public service is mainly relied and determined by human resources that they have. As in principle, the capability of success of an organization is built by the capability of persons in the organization because the machines and various existing facilities shall not have meaning without the persons who have capability (competence) and willingness to take action (commitment). For this reason, the study is conducted and it has purpose to test whether leadership, official's competence, organizational culture and participation of people, either partially or collectively, influence the quality of integrated licensing services of SIUP. This study is located in Bekasi City that consists of 12 sub-districts and 56 urban villages. The findings of this study result can hopefully become input and useful to improve the quality of licensing services and other regions in Indonesia

\section{LITERATURE REVIEW}

The impact on leadership toward the quality of licensing services has been developed in kinds of literature. According to Sanapiah (2000), leadership is one of the key factors in organizational life, including in the public sector and thus in realizing an excellent service, a leader should have the courage to make a change. For this reason, transformational leadership is needed, namely a leadership which is competent as an agent of change. There are five dimensions in transformational leadership, namely an ideal influence that comes from charisma, an ideal influence that is influenced by behavior, and inspirational motivation, intellectual stimulus and individual consideration (Bass and Riggio, 2006:16).

Spencer (1993:5) says that competence is a basic characteristic of a person that is usually related to an effective performance based on certain criteria and/or superior performance in a job or a situation. And then Siregar (2000) states that the official's competence has big contribution toward the quality of services of which in its implementation, it is supported by an adequate rule, an organization with a dynamic mechanism of the system, ability, and skill in accordance with the duties or jobs which are accounted for. Therefore, the availability of services such as infrastructure is in accordance with types and forms of services. There are five dimensions of competence concepts, namely knowledge, skill, self-concept, personal characteristic (traits) and motives (Spencer and Spencer, 1993:9).
According to Tjiptono (2000:75), the quality of service is influenced by many aspects; one of them is the organizational culture and its method of organizing. A good organizational culture will certainly be able to create a good quality of service as well. According to Robbins (2003), the organizational culture is a system of shared meaning held by the members that make different an organization from other organizations. There are seven dimensions of organizational culture variables, namely innovation and risk-taking, attention to details, result-oriented, people-oriented, team-oriented, aggressiveness and stability (Robbins, 1996:209).

Participation may not only become a key word in the development, but also as one of the characteristics of good governance. In general, the meaning of participation of people in the development is a participation of all members or representatives of the people in order to participate in making decision in the process of planning and managing the development, including herein making decision on activity plans that shall be conducted, the benefits that shall be obtained as well as how to implement and evaluate its result of implementation. Cohen and Uphoff (1977) which is quoted by Kaho (2002:115) state that the phases of participation of people may occur in 4 (four) phases, namely: "Participation in decision-making, participation in the implementation, participation in the benefit and participation in the evaluation".

Ibrahim (2008) states that the government should have followed a paradigm of customer-driver (people's interestoriented) in giving service to the public and preparing all components to meet a paradigm systematically so that a qualified public service is realized. The quality of public service is a dynamic condition that relates to the product, service, person, process, and environment where the appraisal of quality is determined while giving such public service (Ibrahim, 2008). A quality can be meant (1) an obedience toward conditions; (2) the compatibility with its use; (3) continuous improvement ; (4) free from any damage/defect; (5) meeting customer's need since early and at any time; (6) performing everything properly; (7) something that can make customer happy (Tjiptono, 1997). According to Parasuraman et al., there are five dimensions of qualities of services (Tjiptono and Chandra, 2005, page 133-135) and those five dimensions include: tangible, reliability, responsiveness, assurance and empathy.

\section{HYPOTHESIS OF STUDY}

This study also has some hypotheses related to the quality of integrated licensing services on SIUP in Bekasi City. These following hypotheses are determined for this study:

H1 : There are significant and positive relationships between leadership and the quality of integrated licensing services on SIUP in Bekasi City.

H2 : There are significant and positive relationships between the official's competence and the quality of integrated licensing services on SIUP in Bekasi City.

H3 : There are significant and positive relationships between the organizational culture and the quality of integrated licensing services on SIUP in Bekasi City.

H4 : There are significant and positive relationships between the participation of people and the quality of integrated licensing services on SIUP in Bekasi City. 
H5 : There are positive and significant relationships collectively between leadership, official's competence, organizational culture and participation of people and the quality of integrated licensing services on SIUP in Bekasi City.

\section{METHOD OF STUDY}

This study includes an explanatory survey of quantitative study. The study with a quantitative approach has a purpose to describe a phenomenon or social symptoms quantitatively or explain on how such phenomenon or social symptoms occurred in the society are related to each other (Nanang Martono, 2015). According to Syofian Siregar (2013), a survey study is a study that may not perform any changes or no special treatment toward variables being studied. Singarimbun dan Effendi (1989:2) states that a survey is a study that takes samples from the population and uses a questionnaire instrument as a data collection means which is made according to the indicators from each dimension in those research variables.

Quantitative analysis uses statistic methods, both descriptive and inferential statistics. Descriptive statistics are meant to describe the characteristics of respondents and the description of study variables, meanwhile inferential statistics use simple and multiple linear regression analysis which has a purpose to test its hypothesis of the study. Then, the result of quantitative analysis is discussed qualitatively by describing every variable of study and discussing the relationships among variables to be then compared with the results of the previous study.

This study uses an explanatory and quantitative survey approach. The method of data collection is made by conducting a field observation and interview and spreading questionnaires to the respondents. Other than the primary data above, the secondary data is obtained from BPS and DPMPTSP website and other relevant kinds of literature. Samples are selected by implementing a random sampling of a proportional stratified technique. The samples collected using Slovin formula are 268 respondents in total. The respondents of this study consist of licensing officers, businessman, academician, LSM (Civil Society Organization) dan the user of people in Bekasi City, West Java Province. Data analysis uses simple and multiple regression analysis. The assumed variables are License Service Quality as a dependent variable (Y), meanwhile, independent variables are Leadership $\left(\mathrm{X}_{1}\right)$, Personnel's Competence $\left(\mathrm{X}_{2}\right)$, Organizational Culture $\left(\mathrm{X}_{3}\right)$ and Participation of People $\left(\mathrm{X}_{4}\right)$. The model can be written statistically as follows:

$$
\hat{Y}=a+b_{1} X_{1}+b_{2} X_{2}+b_{3} X_{3}+b_{4} X_{4}
$$

Where $\mathrm{Y} \quad=$ The quality of integrated licensing services on SIUP

$$
\begin{array}{ll}
\mathrm{X}_{1} & =\text { Leadership } \\
\mathrm{X}_{2} & =\text { Official's competence } \\
\mathrm{X}_{3} & =\text { Organizational culture } \\
\mathrm{X}_{4} & =\text { Participation of People } \\
\mathrm{a} & =\text { Intercept } \\
\mathrm{b} 1 . \mathrm{b} 4 & =\text { coefficient }
\end{array}
$$

\section{RESULT AND DISCUSSION}

Validity is a level of accuracy or instrument feasibility used to measure the things to be measured and how far such instrument carries out its measurement function. The validity of instrument relates to the capability of instrument to measure or disclose the characteristics of variables that want to be measured (Aritonang R, 2007). Validity test is conducted in order to measure the accuracy level or data feasibility. A measuring instrument is valid if it has accuracy toward things that should be measured. Based on statistic calculation result for each variable with 15 items of instruments (in form of questionnaire) and 268 samples of respondents, with the level of significance of $\alpha=0,05$, it is obtained the value of $r_{-}{ }_{\text {count }}$ is higher than $\mathrm{r}_{\text {table }}(0,119)$, so that it can be stated that all items of statements in this questionnaire study are valid.

Reliability can be defined as a reliable thing (timetested). A test can be stated as having high reliability if such test gives a constant result though it is given in a different time to the same respondents. The result of reliability test indicates that all values of reliability coefficients or Alpha Cronbach from each value of study variables are higher than 0,600 or Alpha Cronbach is more than standard Alpha so that it can be stated that all items of statements can be relied as a data collection instrument. According to Joko Widiyanto (2010: $43)$, the value of Alpha Cronbach is higher than $\mathrm{r}_{\text {table }}(0,6)$, thus the questionnaire or all statesments are declared reliable.

\section{Normality and Linearity Tests}

Based on the result of calculation of normality test data, it is known that the whole value of Kolmogorov Smirnov from each variable is higher than 0.05 , thus such data is stated to have a normal distribution or normal data distribution. By using the $F$ test analysis assuming that if $F_{\text {count }}<F_{\text {table, }}$, then its model is linear. Based on the analysis result, it is obtained the value of $\mathrm{F}_{\text {count }}$ is smaller than $\mathrm{F}_{\text {-table }}$ with its degree of correctness (df) $(4 ; 263)$ of 2.406 , then its mode can be stated as linear.

\section{Assumption Test of Classic Deviation}

Classic deviation assumption test under the result of multicolinearty test indicates that all independent variables have tolerance value of more than $0.10(>0.10)$ and all independent variables have the value of Variance Inflation Factor (VIF) less than $10(<10)$, then it can be stated that there is no multicolinearity symptom in this regression model.

\section{Hypothesis Test}

By using statistic program of SPSS version 23, then it is obtained the result of calculation from the t-test and the $f$ test for the test toward five (5) hypothesis that have been shown in Table 1 and Table 2. From that table, it can be known that there are four (4) independent variables that have significant impacts, either partially or collectively toward nonindependent variables. Those four independent variables are leadership $\left(\mathrm{X}_{1}\right)$, personnel's competence $\left(\mathrm{X}_{2}\right)$, organizational culture $\left(\mathrm{X}_{3}\right)$ and participation of people $\left(\mathrm{X}_{4}\right)$, with nonindependent variable of the quality of integrated licensing services on SIUP (Y). Significant impact of leadership, official's competence, organizational culture and participation of people variables toward the quality of licensing services can be seen in the t-value which is for partial impact and the fvalue for collective impact.

Table 1

Validity and Reliability Tests 
Simple Linear Regression Analysis

\begin{tabular}{|l|c|c|l|}
\hline \multirow{2}{*}{ Independent Variables } & \multicolumn{2}{|c|}{ T-Test } & \multirow{2}{*}{ Remark } \\
\cline { 2 - 3 } & t-count & t-table & \\
\hline Leadership $\left(\mathrm{X}_{1}\right)$ & 12.778 & 1.969 & Significant \\
\hline Official's Competence $\left(\mathrm{X}_{2}\right)$ & 20.603 & 1.696 & Significant \\
\hline Organizational Culture $\left(\mathrm{X}_{3}\right)$ & 21.908 & 1.696 & Significant \\
\hline Participation of People $\left(\mathrm{X}_{4}\right)$ & 17.165 & 1.696 & Significant \\
\hline The quality of integrated licensing services on SIUP $(\mathrm{Y})$ \\
\hline
\end{tabular}

Source: Output SPSS 23

Based on the result of study data processing, it is obtained the value of $\mathrm{t}_{\text {-count }}$ higher than $\mathrm{t}_{\text {-table }}$ with $\mathrm{DF}$ (263) of 1.969 and the value of Sig. 000 which means that $t_{-}$count is higher than $\mathrm{t}_{\text {-table }}$, then $\mathrm{H}_{0}$ is rejected and $\mathrm{Ha}$ is accepted. It shows that leadership, official's competence, organizational culture, and participation of people partially impact on the quality of integrated licensing services on SIUP in Bekasi City and it shows that the hypothesis is proved.

Table 2

Multiple Linear Regression Analysis

\begin{tabular}{|c|c|c|c|}
\hline \multirow[t]{2}{*}{ Independent Variables } & \multicolumn{2}{|c|}{ F Test } & \multirow[t]{2}{*}{ Remark } \\
\hline & f-count & $\mathbf{f -}_{\text {table }}$ & \\
\hline Leadership $\left(\mathrm{X}_{1}\right)$ & \multirow{4}{*}{304.034} & \multirow{4}{*}{2.248} & \multirow{4}{*}{ Significant } \\
\hline Official's Competence $\left(\mathrm{X}_{2}\right)$ & & & \\
\hline Organizational Culture $\left(\mathrm{X}_{3}\right)$ & & & \\
\hline Participation of People $\left(\mathrm{X}_{4}\right)$ & & & \\
\hline
\end{tabular}

Source: Output SPSS 23

From the above Table 2, it is obtained the value of fcount of 304.034 and the value of $\mathrm{f}_{\text {table }}$ of $(5 ; 262)$ of 2.248 with the value of Sig. 000 which means that $\mathrm{f}_{\text {- }}$ count is higher than $\mathrm{f}$ table, then $\mathrm{H}_{0}$ is rejected and $\mathrm{H}_{\mathrm{a}}$ is accepted. It indicates that Bekasi City, personnel's competence, organizational culture, and participation of people variables collectively impact on the quality of integrated licensing services on SIUP in Bekasi City and the hypothesis is proved.

\section{Correlation Analysis}

Based on the result of study data processing, it is obtained the value of determination coefficient or $\mathrm{R}^{2}$ of the variable of participation of people of 0.571 . It shows that $57.1 \%$ of the variable of the quality of integrated licensing services on SIUP in Bekasi City is caused by a variable of participation of people, meanwhile the remaining $42.9 \%$ is caused by other variables. For other independent variables, its value of determination coefficient can be seen in this following Table 3:

Table 3

Model Summary
\begin{tabular}{|l|l|l|l|l|l|}
\hline Model & $\mathrm{R}$ & R Square & $\begin{array}{l}\text { Adjusted } \\
\text { R Square }\end{array}$ & $\begin{array}{c}\text { Standard } \\
\text { Error of the } \\
\text { Estimate }\end{array}$ & $\begin{array}{c}\text { Durbin- } \\
\text { Watson }\end{array}$ \\
\hline $\mathrm{X} 1$ & $.876^{\mathrm{a}}$ & .767 & .766 & .19219 & 1.648 \\
\hline $\mathrm{X} 2$ & $.911^{\mathrm{a}}$ & .830 & .829 & .16425 & 1.785 \\
\hline $\mathrm{X} 3$ & $.906^{\mathrm{a}}$ & .822 & .820 & .16832 & 1.875 \\
\hline $\mathrm{X} 4$ & $.756^{\mathrm{a}}$ & .571 & .568 & .26091 & 1.685 \\
\hline
\end{tabular}

Source: Output SPSS 23

The result of determination analysis for service quality variable obtaines the value of determination coefficient or the adjusted $\mathrm{R}^{2}$ of 0.853 . It shows that $85.3 \%$ of the variabel of the quality of integrated licensing services on SIUP in Bekasi City is collectively caused by Bekasi City, official's competence, organizational culture and participation of people variables, meanwhile the remaining $14.7 \%$ is caused by other variables.

\section{Linear Regression Equation}

Based on the result of linear regression analysis, it is obtained the value of simple linear regression equation shown in this following Table 4:

Table 4

Simple Linear Regression Equation

\begin{tabular}{|l|l|}
\hline \multicolumn{1}{|c|}{ Independent Variables } & \multicolumn{1}{c|}{$\begin{array}{c}\text { Linear Regression } \\
\text { Equation }\end{array}$} \\
\hline Leadership $\left(\mathrm{X}_{1}\right)$ & $\hat{\mathrm{Y}}=2,570+0383 \mathrm{X} 1$ \\
\hline Official's Competence $\left(\mathrm{X}_{2}\right)$ & $\hat{\mathrm{Y}}=1.617+0.608 \mathrm{X}_{2}$ \\
\hline Organizational Culture $\left(\mathrm{X}_{3}\right)$ & $\hat{\mathrm{Y}}=1.518+0,643 \mathrm{X}_{3}$ \\
\hline Participation of People $\left(\mathrm{X}_{4}\right)$ & $\hat{\mathrm{Y}}=1.512+0.651 \mathrm{X}_{4}$ \\
\hline
\end{tabular}

Source: Output SPSS 23

Table 5

Multiple Linear Regression Analysis

\begin{tabular}{|c|c|c|c|c|c|c|c|}
\hline \multirow[b]{2}{*}{ Model } & \multicolumn{2}{|c|}{$\begin{array}{l}\text { Unstandardized } \\
\text { Coefficients }\end{array}$} & \multirow{2}{*}{$\begin{array}{l}\text { Standardized } \\
\text { Coefficients } \\
\text { Beta }\end{array}$} & \multirow[b]{2}{*}{$\mathrm{T}$} & \multirow[b]{2}{*}{ Sig. } & \multicolumn{2}{|c|}{$\begin{array}{l}\text { Collinearity } \\
\text { Statistics }\end{array}$} \\
\hline & B & $\begin{array}{l}\text { Standard } \\
\text { Error }\end{array}$ & & & & Tolerance & VIF \\
\hline 1 (Constant) & .511 & .128 & & 4.009 & .000 & & \\
\hline $\mathrm{X}_{1}$ & .033 & .030 & .032 & 1.087 & .278 & .633 & 1.580 \\
\hline $\mathrm{X}_{2}$ & .241 & .038 & .207 & 6.266 & .000 & .514 & 1.946 \\
\hline$X_{3}$ & .295 & .038 & .261 & 7.716 & .000 & .490 & 2.041 \\
\hline $\mathrm{X}_{4}$ & .321 & .026 & .356 & 12.310 & .000 & .670 & 1.494 \\
\hline
\end{tabular}

The above Table 5 indicates the result of multiple regression analysis by resulting this following equation of multiple linear regression:

$\hat{Y}=0.511+0.033 X_{1}+0.241 X_{2}+0.295 X_{3}+0.321 X_{4}$

Such equation of multiple linear regressions above has these following meanings:

- That every increase of 1 point of leadership variable impacts on the increase of point of the variable of the quality of integrated licensing services on SIUP in Bekasi City of 0.033 assuming that the official's competence, organizational culture, and participation of people variables are constant.

- That every increase of 1 point of official's competence variable impacts on the increase of point of the variable of the quality of integrated licensing services on SIUP in Bekasi City of 0.241 assuming that Bekasi City, organizational culture dan participation of people variables are constant.

- That every increase of 1 point of organizational culture variable impacts on the increase of point of the variable of the quality of integrated licensing services on SIUP in Bekasi City of 0.295 assuming that Bekasi City, official's 
competence and participation of people variables are constant.

- That every increase of 1 point of participation of people variable impacts on the increase of point of variable of the quality of integrated licensing services on SIUP in Bekasi City of 0.321 assuming that Bekasi City, official's competence and organizational culture variables are constant.

\section{The Implication of Study}

The implication of this study is a positive attitude of the people, in this case, the respondents that give their statement that an effective transformational leadership has important role in realizing the quality of licensing services on SIUP in Bekasi City which is supported by a professional official's competence, a strong organizational culture and the participation of people. The effectiveness of leadership and official's competence can be obtained by the participation of people and government officials through planning, implementation, acceptance, and use of results as well as the supervision and appraisal of result in realizing an excellent quality of service because upon participation of people and government officials, it shall be obtained an alternative solution in handling problems related to the licensing services on SIUP in Bekasi City.

Based on the study result, these efforts are necessary to be conducted as follows: first, there is a need to improve the integrity, creativity and innovation of transformational leadership in order to improve the quality of fast, easy and transparent services. Secondly, there is a need to improve the official's competence in improving their level of knowledge, analytical and systematic thinking ability as well as improve the skills in developing the services. Thirdly, there is a need to strengthen an organizational culture by improving its service and supporting facilities in accomplishing the work by using information and communication technology as well as the increase of the official's attention to details. Forthly, there is a need to increase the participation of people by increasing people's involvement in service problem analysis in determining the need for services and in determining targets. Fast and proper following up efforts are conducted by government officials or licensing authority if there is a critism, suggestion, opinion and appraisal of people toward licensing service. Fifthly, the quality of service necessarily managed is to improve the standard of service, either the time, service fee, the increase of insurance cost, time and service legality as well as the effort to improve the facility, cleanliness, neatness and comfort of the service rooms. It also includes the effort to improve an integrated one-stop service up to the issuance of its permit.

\section{CONCLUDING REMARKS}

This study has a finding that Bekasi City, official's competence, organizational culture and participation of people, either partially or collectively have a significant impact on the quality of integrated licensing services on SIUP in Bekasi City.

Such finding above shows that the attention to increase the participation of people in giving an effective control and improve the facility of integrated licensing service through information and communication technology. The impact of official's competence variable which is very significant proves that the role of human capital is very strategic in improving the quality of service. The quality of integrated licensing services on SIUP in Bekasi City is the entryway to introduce and develop good governance, where Bekasi City, official's competence, organizational culture, and participation of people are very important factors in supporting and realizing good governance in scope of integrated licensing services on SIUP in Bekasi City.

\section{REFERENCES}

[1] Abdussamad, Zuchri.2014. Kompetensi Aparat dalam Pelayanan Publik. Cetakan Pertama Yogyakarta.

[2] Aritonang, R. Lerbin, R. 2007. Teori dan Praktik Riset Pemasaran. Bogor: Ghalia Indonesia.

[3] Bass, Bernard M dan Riggio, Ronald E.2006. Transformasional Leadership. Second Edition, London: Lawrance Erlbaum Associates Publisher.

[4] David Osborn dan Ted Gaebler. 1992. Reinventing Government: How the Entrepreneur Spirit is Transforming the Public Service. Terjemahan: Mewirausahakan Birokrasi Mentransformasikan Semangat Wirausaha ke Dalam Sektor Publik. Alih Bahasa Abdul Rosyid dan Ramelan. Jakarta: Pustaka Binaman Pressindo.

[5] Dwiyanto. A., 2008. Mewujudkan Good Government Melalui Pelayanan Publik: Cetakan Revisi 3. Yogyakarta: Gajah Mada University Press.

[6] Hardiansyah, 2018. Kualitas Pelayanan Publik. Yogyakarta: Gava Media.

[7] Ibrahim, A., 2008. Teori dan Konsep Pelayanan Publik serta Implementasinya. Bandung: Mandar Maju.

[8] Ismaniah, forthcoming. Pengaruh Kepemimpinan, Kompetensi Aparat, Budaya Organisasi dan Partisipasi Masyarakat terhadap Kualitas Pelayanan Terpadu Perizinan SIUP di Kota Bekasi, Ph.D thesis, University of Satyagama, Jakarta.

[9] Kaho, Josep Riwu. 2002. Prospek Otonomi Daerah di Negara Republik Indonesia. (Identifikasi beberapa faktor yang mempengaruhi penyelenggaraannya). Jakarta: PT. Raja Grafindo Persada.

[10] Kerlinger, Fred. N dan Elazar Pedhazur. 1973. Multiple Regression in Behavioral research. New-York: Holt, Rinehart and Winstons.

[11] Nawawi, Ismail., 2017. Budaya Organisasi, Kepemimpinan \& Kinerja: Proses Terbentuk, Tumbuh Kembang, DInamika, dan Kinerja Organisasi. Cetakan ketiga, Depok: Kencana.

[12] Ndraha, T., 1997. Budaya Organisasi, Jakarta: Rineka Cipta.

[13] Pamudji, S., 1994. Profesionalisme Aparatur Negara Dalam Meningkatkan Pelayanan Publik. Jakarta: Gramedia.

[14] Parasuraman, A., Valarie A Zeithhaml \& Leonard L., Berry, 1985, “A Conceptual Model of Service Quality and Implication For Future Service" Jornal of Marketing, 49 (Fall), p.41-50.

[15] Robbins. 1996. Perilaku Organisasi, KonsepKontroversi Aplikasi, Edisi Bahasa Indonesia, Jakarta, PT. Prenhalindo.

[16] Sanapiah Azis. 2000. Pelayanan yang berorientasi kepada kepuasan masyarakat Administrasi Negara Vol 6 Nomor 1. 
[17] Siregar, Ashadi, dan Rondang Pasaribu. 2000. Media Korporasi, Organisasi, Lembaga Penelitian Pendidikan dan Penerbitan Yogyakarta. Yogyakarta.

[18] Spencer, Lyle M. Jr, and Signe Spencer. 1993. Competence At Work, Models For Superior Performance. United States of America: John Wiley \& Sons.Inc.

[19] Tjiptono, H.S., 1997. Prinsip-PrinsipTtotal Quality Service. Yogyakarta: Andi.
[20] Uphoff, NT.,Cohen, JM., dan Goldsmith, AA.,1997. Rural Development Committee: Feasibility and Application of Rural Development Participation: A. State-of-the-Arth Paper. New York: Cornell University.

[21] Zeithaml, V.A., A. Parasuraman \& Leonard L. Berry. 1990. Delivering Quality Service: Balancing Custumer Perception and Expectations. New York: The Free Press, MacMilan 